\title{
Perineal pain measurement in the immediate vaginal postpartum period
}

\author{
Mensuração da dor perineal no pós-parto vaginal imediato
}

Ana Eliza Rios de Araújo Mathias ${ }^{1}$, Ana Carolina Rodarti Pitangui ${ }^{1}$, Amanda Mariáh Araújo Vasconcelos ${ }^{1}$, Suellen Souza Silva1 ${ }^{1}$ Paloma dos Santos Rodrigues ${ }^{1}$,Thaís Guimarães Dias ${ }^{1}$

DOI 10.5935/1806-0013.20150054

\section{ABSTRACT}

BACKGROUND AND OBJECTIVES: Postpartum is a period where there are physiological changes in women's body, and most of them suffer perineal trauma during the expulsion period, which may induce perineal pain and is considered the most common cause of postpartum morbidity. This study aimed at measuring perineal pain in the immediate vaginal postpartum period and the possible association with its risk factors.

METHODS: Participated in the study 147 vaginal postpartum women in the period from September 2013 to May 2014. Data collection tools were personal data files, socio-demographic and clinical characteristics, McGill Pain Questionnaire and pain numerical scale.

RESULTS: From all evaluated women, 76 (51.7\%) reported pain in the immediate postpartum period. Among respondents with pain, $51(67.1 \%)$ were primiparous, 71 (93.4\%) had suffered some perineal trauma, $55(72.3 \%)$ had babies weighing above $3 \mathrm{~kg}$, and 41 (53.9\%) were above 21 years of age. Mc Gill Pain Questionnaire sensory characteristics were the most commonly mentioned and pain was associated to episiotomy $(\mathrm{p}=0.002)$ and laceration $(\mathrm{p}=0.039)$. There has also been significant association between pain and parity $(\mathrm{p}=0.028)$.

CONCLUSION: Pain was present in more than half the studied population, showing an association with variable parity and perineal trauma.

Keywords:Pain, Parity, Postpartum period.

\section{RESUMO}

JUSTIFICATIVA E OBJETIVOS: O puerpério é um período em que ocorrem mudanças fisiológicas no corpo da mulher, e a maioria delas sofre trauma perineal no período expulsivo, que pode ocasionar dor perineal,e é considerada a causa mais comum de morbidade no puerpério. $\mathrm{O}$ objetivo deste estudo foi mensurar a dor perineal no pós-parto vaginal imediatoe a possível associaçáo com os seus fatores de riscos.

MÉTODOS: Foram avaliadas 147 puérperas que tiveram parto vaginal durante os meses de setembro de 2013 a maio de 2014 . Os instrumentos utilizados para coleta de dados foram ficha de dados pessoais, características sócio-demográficas e clínicas; questionário McGill PainQuestionnaire; e escala numérica da dor. RESULTADOS: Das mulheres avaliadas, 76 (51,7\%) relataram sentir dor no período imediato ao parto. Dentre as entrevistadas que sentiram dor $51(67,1 \%)$ eram primíparas, $71(93,4 \%)$ sofreram algum trauma perineal, 55 (72,3\%) tiveram seu recémnascido pesando acima de $3 \mathrm{~kg}$, e $41(53,9 \%)$ tinham acima de 21 anos de idade. A característica sensorial referente ao McGill PainQuestionnairefoi a mais citada, e a dor esteve associada à presença de episiotomia $(p=0,002)$, e laceração $(p=0,039)$. Ainda, observou-se associação significativa entre a presença de dor e a paridade $(\mathrm{p}=0,028)$.

CONCLUSÃO: A dor foi presente em mais da metade da população estudada, demonstrando associação com as variáveis paridade e trauma perineal.

Descritores: Dor, Paridade, Período pós-parto.

\section{INTRODUCTION}

Postpartum is a period when there are physiological changes in women's body and most of them suffer some type of perineal injury during delivery, which may lead to morbidities, especially pain ${ }^{1-3}$. Among factors increasing chances of maintaining perineal integrity are number of previous vaginal deliveries and neonatal (NN) weight below $3.125 \mathrm{~g}^{4}$.

Loss of genital tissues integrity during delivery is called perineal trauma and may be caused by surgical incision such as episiotomy, or spontaneous injury, called laceration. Some complications may be triggered by such injuries, such as urinary and fecal incontinence, dyspareunia and pelvic floor disorders $^{5-8}$.

Perineal laceration is classified as first degree when reaching skin and mucosa; second degree when extending to perineal muscles; and third degree when reaching anal sphincter muscle. These injuries depend on several factors related to mother, 
fetus and delivery conditions ${ }^{9}$. In turn, episiotomy is a surgical strategy applied during expulsion aiming at preventing perineal lacerations. However, sometimes it may become a more severe perineal trauma than spontaneous laceration, being clinically identified by incision of superficial transverse muscles of perineum and bulbocavernosus, in addition to skin and mucosa.

Some factors increase episiotomy rate, such as nulliparity, prematurity, poorly distensible perineum with tense muscles, maternal exhaustion, transpelvic operations, such as forceps or vacuum extraction and pelvic presentation ${ }^{4,9,10}$. Among morbidities caused by episiotomy on vaginal introitus during delivery, one may mention vaginal bleeding, infection, suture dehiscence and hematomas, which may trigger perineal pain and urinary and fecal incontinence, thus interfering with breastfeeding ${ }^{6,8,10}$.

The Ministry of Health considers the liberal or routine use of episiotomy as clearly harmful or ineffective, which should be eliminated ${ }^{11}$. Data of National Research of Children and Women Demographics and Health 2006 (PNDS) ${ }^{12}$ show that the high frequency of episiotomies (71.6\%), especially in Southeastern (80.3\%), Midwest $(78.8 \%)$ and Southern $(78.5 \%)$ regions, reveal the routine use of this practice and, consequently, predominance of a more interventionist model also during vaginal delivery in Brazil. On the other hand, there are reports on lack of measures contributing to women's comfort. So, the assistance of health professionals to women in the postpartum period is priority, so that morbidities caused by perineal trauma, especially pain, are identified and appreciated ${ }^{3}$.

Perineal pain is described by the literature as a frequent sequela of the delivery process, being characterized as acute and considered common cause of postpartum morbidity ${ }^{13}$. Acute pain leads individuals to manifest symptoms such as sleep pattern, appetite and libido changes, irritability, energy changes, decreased concentration capacity, restriction in family, professional and social activities capacity ${ }^{14}$.

In this sense, it is necessary to study perineal pain in the immediate postpartum period after vaginal delivery because the evaluation of such pain may encourage health professionals involved with vaginal delivery to better understand the consequences to quality of life of parturients due to a poorly elaborated approach, improving assistance during and after delivery. So, this study aimed at measuring perineal pain in the immediate post-vaginal delivery period and its association with possible risk factors.

\section{METHODS}

This was a descriptive cross-sectional study developed in the delivery room and ward of the joint lodging of Hospital Dom Malan (Administration IMIP) and Maternidade de Juazeiro, located in the city of Petrolina/PE and Juazeiro/BA, respectively. Sample was made up of 147 women submitted to vaginal delivery. Data were collected from September 2013 to May 2014.
Inclusion criteria were women with low risk gestation, in post-vaginal delivery period with or without perineal trauma, primiparous and multiparous. Exclusion criteria were diagnosed urinary tract infection, twin gestation or history of recurrent abortion, women victim of sexual violence/abuse, previous or current diagnosed depression, not speaking or understanding Portuguese.

A pilot study was carried out with 10 mothers to check understanding and efficacy of data collection tools and possible research procedures biases, corrections or limitations.

The following data collection tools were used to evaluate mothers: personal data chart with socio-demographic and clinical characteristics of interviewed women. McGill Pain Questionnaire (MPQ) ${ }^{15,16}$ was used to measure pain, which is a multidimensional tool evaluating different pain aspects by means of words chosen by patients to express it. Descriptors are divided in four groups: discriminative sensory, motivational affective, cognitive evaluative and miscellaneous. Results may be reached by a numeric index of descriptors, which is the number of words chosen by participants to characterize their pain, being maximum score 20 , because volunteers shall only choose one word for each subgroup, or by pain index calculated by the sum of intensity scores of each descriptor (0-5), with maximum score of 8 .

In addition, numeric visual pain scale (NVS) was used, which consists in a one-dimension scale easy to apply and to be understood by patients. It is made up of a horizontal line with numbers from zero to 10 and on its edges there are the following expressions: "no pain" (zero) and "unbearable pain" (10). Participants should mark in the line the number corresponding to their pain and the higher the score the higher the intensity of pain ${ }^{17}$.

Patients were evaluated only once with a minimum of $6 \mathrm{~h}$ and maximum of $24 \mathrm{~h}$ after delivery. This period was related, respectively, to the moment women could already leave bed and end of analgesia, in case it had been used; and limit of $24 \mathrm{~h}$, related to injury acute phase, inflammatory process and higher predominance of pain. In case mothers had used some pain relief resource, the period of its effect was controlled based on drug dose, thus considering possible interferences with initial pain evaluation ${ }^{17-19}$.

Data were collected by two duly trained evaluators who made jointly evaluations. One evaluator was in charge of interviewing mothers while the other took notes in the evaluation chart.

Non-probabilistic sample was intentional and by convenience, and data were processed and analyzed by the Statistical Package for the Social Sciences (SPSS) version 16 (SPSS Inc., Chicago, IL, United States of America, Release 16.0.2, 2008). Exploratory analysis of variables was carried out after coding variables in a database and validation by double entry. Analysis of results was descriptive and analytical. Initially, data normality was checked and if distribution was symmetrical, central trend and dispersion measures were used for continuous variables presentation, or central trend measures added to separatrices when distribution was non-parametric. 
Prevalence and possible associations were calculated with Pearson Chi-square test or Fisher Exact test. For all analyses significance level was $\mathrm{p} \leq 0.05$. Confidence intervals (CI), when determined, were exact.

This study has posed minimum risks to participants, being these related to embarrassment in answering questions. So, questions were privately asked just to participants, without having other people interfering with answers. In addition, in case of some postpartum depression symptom or pain observed during interview, researcher has referred patient to specialized professionals for assistance. Benefits of the study were possible identification of pain intensity of mothers, and so provide early intervention in women's health care.

This study has followed ethical determinations for research with human beings, according to the Declaration of Helsin$\mathrm{ki}, 2000$. We have also complied with guidelines and standards regulating research with human beings, of resolution 466, from December 12, 2012. Participants have signed the Free and Informed Consent Term (FICT) and were informed about the secrecy of collected data.

This study was approved by the Research Ethics Committee Universidade de Pernambuco, under protocol 412.370/2013.

\section{RESULTS}

The study has evaluated 147 postpartum women with median age of 21 years, varying from 14 to 39 years, prenatal consultation median of 7 , being between zero and 15 consultations, and NN weight with median of $3.196 \mathrm{~g}$. Table 1 shows sociodemographic and clinical aspects of patients.

Among analyzed women, it was observed that 76 (51.7\%) have reported some pain in the immediate postpartum period. Table 2 shows the association between pain and evaluated factors.

Most reported pain score by mothers was moderate with mean score of $.22 \pm 2.31$ varying from one to 10 . Most prevalent scores were 5 reported by $21(27.6 \%)$ mothers, followed by 4 by 11 women $(14.5 \%)$ and $7(13.7 \%)$. Remaining scores were referred by 34 (44.7\%) women with pain. Table 3 shows MPQ questionnaire results where postpartum pain characteristics were delineated.

Table 1. Socio-demographic and clinical characteristics of mothers interviewed in the joint lodging of Hospital Dom Malan IMIP Administration in Petrolina PE and Maternidade Juazeiro in Juazeiro-BA

\begin{tabular}{lccc}
\hline Variables & $\mathrm{n}$ & $\%$ & $\mathrm{Cl}_{95 \%}$ \\
\hline Marital status & & & \\
$\quad$ With companion & 129 & 87.8 & $81.34-92.58$ \\
$\quad$ Without companion & 18 & 12.2 & $7.42-18.66$ \\
Family income (MW) & & & \\
Up to 1 & 88 & 59.9 & $51.47-67.85$ \\
$1-2$ & 48 & 32.7 & $25.44-40.54$ \\
$>2$ & 11 & 7.5 & $3.79-12.99$ \\
\hline
\end{tabular}

Table 1. Socio-demographic and clinical characteristics of mothers interviewed in the joint lodging of Hospital Dom Malan IMIP Administration in Petrolina PE and Maternidade Juazeiro in Juazeiro-BA - continuation

\begin{tabular}{|c|c|c|c|}
\hline Variables & $\mathrm{n}$ & $\%$ & $\mathrm{Cl}_{95 \%}$ \\
\hline \multicolumn{4}{|l|}{ Education } \\
\hline $\begin{array}{l}\text { Incomplete and complete basic } \\
\text { education }\end{array}$ & 70 & 47.6 & $39.33-56.01$ \\
\hline $\begin{array}{l}\text { Incomplete and complete high } \\
\text { school }\end{array}$ & 70 & 47.6 & $39.33-56.01$ \\
\hline Incomplete and complete college & 7 & 4.8 & $1.94-9.57$ \\
\hline \multicolumn{4}{|l|}{ Paid activity } \\
\hline Yes & 47 & 32 & $24.53-40.16$ \\
\hline No & 100 & 68 & $59.84-75.47$ \\
\hline \multicolumn{4}{|l|}{ Parity } \\
\hline Primiparous & 85 & 57.8 & $49.41-65.91$ \\
\hline Multiparous & 62 & 42.2 & $34.09-50.59$ \\
\hline \multicolumn{4}{|l|}{ Perineal trauma } \\
\hline Episiotomy & 34 & 23.1 & $16.58-30.79$ \\
\hline Laceration & 74 & 50.3 & $41.98-58.68$ \\
\hline Without perineal trauma & 42 & 28.6 & $21.43-36.60$ \\
\hline \multicolumn{4}{|l|}{ Body mass index } \\
\hline Obesity & 5 & 3.4 & $1.11-7.76$ \\
\hline Overweight & 28 & 19 & $13.05-26.34$ \\
\hline Eutrophic & 73 & 49.7 & $41.32-58.02$ \\
\hline Low weight & 39 & 26.5 & $19.60-34.44$ \\
\hline
\end{tabular}

$\mathrm{n}=$ relative frequency; $\%=$ absolute frequency; $\mathrm{Cl}=$ confidence interval; $\mathrm{MW}$ $=$ minimum wage

Table 2. Association of perineal pain and variables age, neonatal weight, parity and perineal trauma

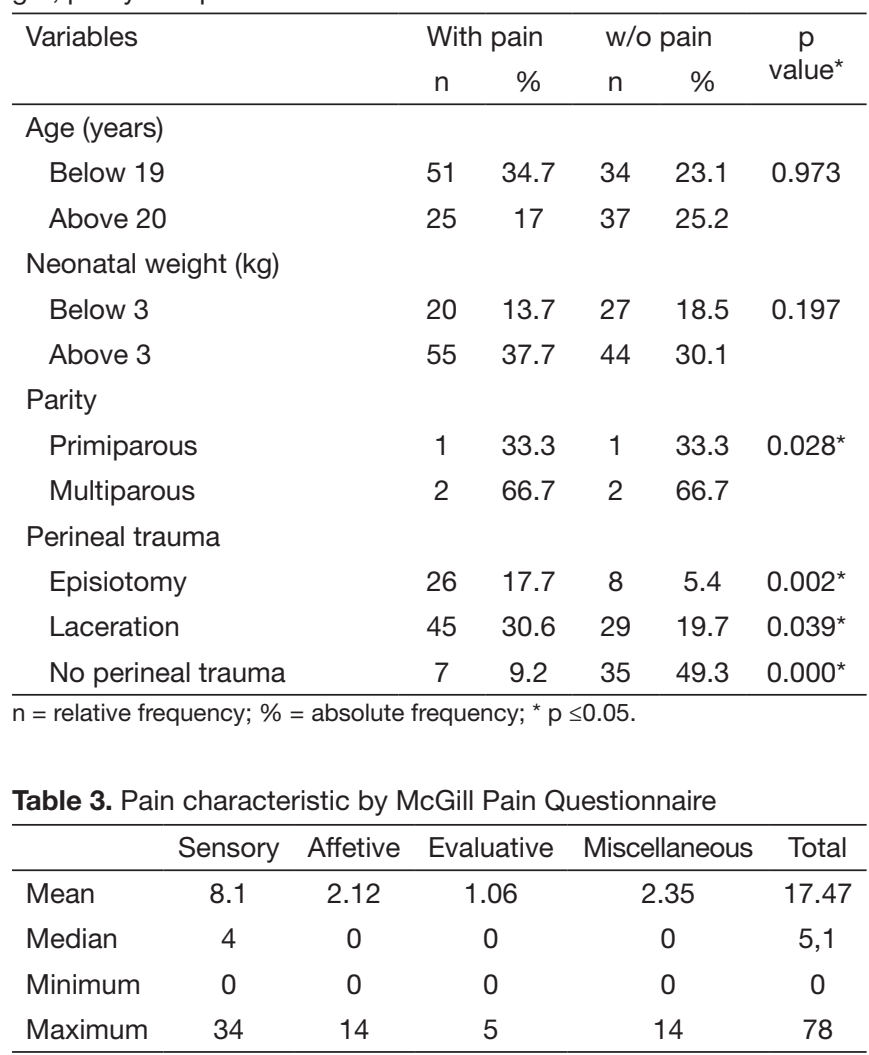




\section{DISCUSSION}

Our study has observed high prevalence of perineal trauma after vaginal delivery, where the frequency of episiotomy was $23.1 \%$, and of laceration $50.3 \%$ among perineal traumas. Confirming our study, Mouta et al. ${ }^{20}$ have found $73.4 \%$ of perineal traumas, of which $68.52 \%$ were lacerations. On the other hand, Santos et al. ${ }^{2}$ have shown that from 279 analyzed medical charts, there has been episiotomy without laceration in $86.99 \%$ of women.

Risks of the routine use of episiotomy are well known, stressing that its restricted use has clear advantages, such lower incidence of posterior perineal trauma or more severe perineal traumas, lower incidence of pain and postpartum complications, in addition to the lack of evidence of better maternal or perinatal results with episiotomy ${ }^{8}$.

Our study has shown association between pain and perineal traumas, however there has been further association of pain with episiotomy. In this context, women being submitted to episiotomy may have twice as much perineal pain complaints as compared to a group with intact perineum ${ }^{21}$ and pain may be milder when women exercise during labor; maternal immobility may also contribute for the increased number of dystocias and risk for C-section, for impairing fetal progression or descent ${ }^{22}$.

With regard to the association between pain and parity, there has been association between such factors, where 51 (34.7\%) primiparous and 25 (17\%) multiparous have reported perineal pain. So, one may say that some difficulties suffered by primiparous during delivery, such as unawareness and lack of preparation, experience of a high number of negative emotions, concern with baby's health, may lead to lengthy labor and generate postpartum pain ${ }^{23}$.

With regard to age, 147 mothers with median age of 21 years, varying from 14 to 39 years were evaluated, and pain was present in 35 (46.1\%) women up to 21 years of age and in $41(53.9 \%)$ women above 21 years of age, but this marker has not shown association with pain. Similarly, there has been no association between pain and NN weight. These data might not have been associated due to the small sample size associated to a wide variety in $\mathrm{NN}$ weight and maternal age marker values.

With regard to pain measurement, interviews have quantified postpartum perineal pain as moderate, being 5 the most frequently mentioned intensity, confirming Beleza et al. ${ }^{13}$ who have evaluated pain level referred by mothers after delivery with episiotomy and have found pain intensity of 4 (median value), being minimum of 1 and maximum of 10. Mean and standard deviation were 5 and 2.07, respectively.

Some factors might be related to increased pain in the puerperal period, such as excessive number of digital vaginal examinations, due to the risk of changes in regional tissues, and lengthy labor which may pose a risk for the perineal region and may represent further genital manipulation resulting in pain during the puerperal period ${ }^{13}$.
In our study, to describe post-vaginal delivery pain characteristics, we have used MPQ, where most respondents have referred their pain as having sensory character, with 34 women referring such descriptor. Similar result was found by Pitangui et al. ${ }^{17}$ where most women have chosen sensory descriptors as those best defining post-episiotomy pain.

According to Pimenta \& Teixeira $^{16}$, multidimensional pain evaluation tools are used to show interaction between patients and health professionals about pain. So, it is necessary an understanding of pain for the implementation of analgesic measures and evaluation of therapeutic efficacy.

In light of the above, we expect that prevalence found in this study may show the need to identify and characterize perineal pain in puerperal women, to prevent future complications. In addition, we expect that presented results may support a new approach of health professionals during labor, in search for better quality of life for postpartum women.

\section{CONCLUSION}

Perineal pain was the most relevant pain in this sample, showing association with variables parity and perineal trauma. However, it was not possible to associate perineal pain and variables NN weight and age. So, there is the need for a multidisciplinary intervention directed to women's health and especially to pain relief during immediate postpartum period.

\section{REFERENCES}

1. Bertozzi S, Londero AP, Fruscalzo A, Driul L, Marchesoni D. Prevalence and risk factors for dyspareunia and unsatisfying sexual relationships in a cohort of primiparous and secondiparous women after 12 months postpartum. Int J Sexual Health. 2010;22(1):47-53

2. Santos JO, Bolanho IC, Mota JQ, Coleoni L, Oliveira MA. Frequência de lesóes perineais ocorridas nos partos vaginais em uma instituição hospitalar. Esc Anna Nery. 2008;12(4):658-63.

3. Riesco ML, Costa AS, Almeida SF, Basile AL, Oliveira SM. Episiotomia, laceração e integridade perineal em partos normais: análise de fatores associados. Rev Enferm UERJ. 2011;19(1):77-83.

4. Johanson R. Perineal massage for prevention of perineal trauma in childbirth. Lancet. 2000;335(9200):250-1.

5. Albers LL, Borders N. Minimizing genital tract trauma and related pain following spontaneous vaginal birth. J Midwifery Womens Health. 2007;52(3):246-53.

6. Almeida SF, Riesco ML. Randomized controlled clinical trial on two perineal trauma suture techniques in normal delivery. Rev Lat Am Enfermagem. 2008;16(2):272-9.

7. Carroli G, Mignini L. Episiotomy for vaginal birth. Cochrane Database Syst Rev. 2009;(1):CD000081.

8. Scarabotto LB, Riesco ML. [Factors related to perineal trauma in normal births in nulliparous]. Rev Esc Enferm USP. 2006;40(3):389-95. Portuguese.

9. Costa AV, Sales RM, Moura FM, Costa RS, Moura LJ. Vivência das mulheres sobre a episiotomia. Rev Enferm UFPI. 2012;1(1):50-5.

10. Brasil. Ministério da Saúde. Secretaria de Políticos de Saúde. Área Técnica de Saúde da Mulher. Parto, aborto e puerpério: assistência humanizada à mulher/ Ministério da Saúde, Secretaria de Políticas de Saúde, Área Técnica da Mulher. - Brasília: Ministério da Saúde, 2001

11. Brasil. Ministério da Saúde. Pesquisa Nacional de Demografia e Saúde da Criança e da Mulher - PNDS 2006: dimensôes do processo reprodutivo e da saúde da criança/ Ministério da Saúde, Centro Brasileiro de Análise e Planejamento. - Brasília: Ministério da Saúde, 2009.

12. Francisco AA, Oliveira SM, Santos JO, Silva FM. Avaliaçáo e tratamento da dor perineal no pós-parto vaginal. Acta Paul Enferm. 2011;24(1):94-100.

13. Beleza AC, Ferreira $\mathrm{CH}$, Sousa L, Nakano A. Mensuração e caracterização da dor após episiotomia e sua relaçáo com a limitaçáo de atividades. Rev Bras Enferm, Brasília. 2012;65(2):264-8.

14. Kreling MC, da Cruz DA, Pimenta CA. [Prevalence of chronic pain in adult workers]. 
Rev Bras Enferm. 2006;59(4):509-13. Portuguese.

15. Martinez JE, Grassi DC, Marques LG. Análise da aplicabilidade de três instrumentos de avaliação de dor em distintas unidades de atendimento: ambulatório, enfermaria e urgência. Rev Bras Reumatol. 2011;51(4):304-8.

16. Pimenta CA, Teixeira MJ. [Proposal to adapt the McGill Pain Questionnaire into Portuguese]. Rev Esc Enferm USP. 1996;30(3):473-83. Portuguese.

17. Pitangui AC, Sousa L, Ferreira CH, Gomes FA, Nakano AM. Mensuraçấo e características da dor perineal em primíparas submetidas à episiotomia. Acta Paul Enferm. 2009;22(1):77-82.

18. Pitangui AC, Araújo RC, Bezerra MJ, Ribeiro CO, Nakano, AM. Low and highfrequency TENS in post-episiotomy pain relief: a randomized, double-blind clinical trial. Braz J Phys Ther. 2014;(18):72-8.

19. Pitangui AC, de Sousa L, Gomes FA, Ferreira CH, Nakano AM. High-frequency
TENS in post-episiotomy pain relief in primiparous puerpere: a randomized, controlled trial. J Obstet Gynaecol Res. 2012;38(7):980-7.

20. Mouta RJ, Pilotto DT, Varens OM, Progianti JM. Relação entre posição adotada pela mulher no parto, integridade perineal e vitalidade do recém-nascido. Rev Enferm UERJ. 2008;16(4):472-6.

21. Tomasso G, Althabe F, Cafferata ML, Alemán A, Sosa C, Belizán JM. Debemos seguir haciendo la episiotomía en forma rutinaria? Rev Obstet Gynecol Venezuela. 2002;62(2):115-21.

22. Zwelling E. Overcoming the challenges: maternalmovement and positioning to facilitate labor progress.MCN Am J Matern Child Nurs. 2010;35(2):72-8.

23. Costa RA, Figueiredo BC, Pacheco AP, Pais A. Parto: expectativas, experiências, dor e satisfaçấo. Psicologia, Saúde \& Doenças. 2003;4(1):47-67. 